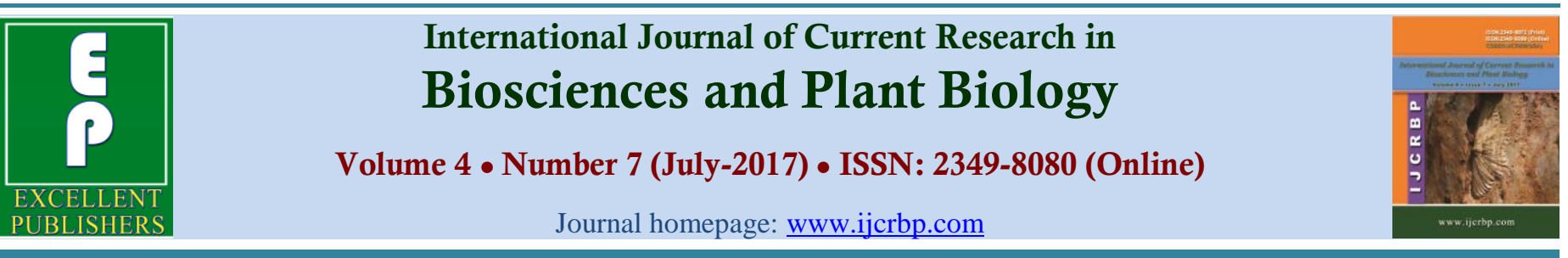

\title{
Aflatoxin B1 Contamination Correlation with Aspergillus flavus in Animal Feed Raw Materials Imported through the Port of Tanjung Perak Surabaya, Indonesia
}

\author{
Yunetta Putri Arios ${ }^{1 *}$, Agustin Indrawati ${ }^{2}$ and Joko Pamungkas ${ }^{2}$
}

\begin{abstract}
${ }^{1}$ Indonesian Agricultural Quarantine Agency, Ministry of Agriculture, Stasiun Karantina Pertanian Kelas I Merauke, Indonesia ${ }^{2}$ Department of Animal Diseases and Veterinary Public Health, Faculty of Veterinary Medicine, Bogor Agricultural Universty, Bogor 16680, West Java, Indonesia
\end{abstract}

*Corresponding author.

\begin{tabular}{|c|c|}
\hline Abstract & Article Info \\
\hline \multirow{6}{*}{$\begin{array}{l}\text { This study aimed to measure the incidence rate of aflatoxin B1 contamination in feed raw } \\
\text { materials (MBM and PPM) imported through Port of Tanjung Perak Surabaya, and its } \\
\text { relation to the growth of the fungi that produce it. ELISA (Enzyme Linked } \\
\text { Immunosorbent Assay) competitive was conducted to identify Aflatoxin B1 and followed } \\
\text { by HPLC (High Performance Liquid Chromatography). Fungal identification was } \\
\text { conducted as a macroscopic and microscopic observation. ELISA test showed } 55 \text { of } 84 \\
\text { (55.95\%) samples were positive for aflatoxin B1 contamination, while } 3 \text { of } 7(42.85 \%) \\
\text { samples tested by HPLC were positive. The result of fungal identification showed } 1 \text { of } 12 \\
\text { samples positive Aspergillus flavus, and others types of fungi. AFB1 contamination in } \\
\text { animal feed raw materials is likely to have occurred in the country of origin, whereas the } \\
\text { growth of the fungus is due to the level of humidity and temperature during the } \\
\text { transportation and storage process. }\end{array}$} & $\begin{array}{l}\text { Accepted: } 13 \text { June } 2017 \\
\text { Available Online: } 06 \text { July } 2017\end{array}$ \\
\hline & Keywords \\
\hline & Aflatoxin B1 \\
\hline & Aspergillus flavus \\
\hline & Raw animal feed \\
\hline & Surabaya \\
\hline
\end{tabular}

\section{Introduction}

Human resources quality of a nation is influenced by many factors including the nutritional intake, especially the adequacy of animal protein. In this case, livestock has an important role to fulfill the adequacy of animal protein. The quality of fodder plays a very important role, because the meat that is expected to meet the adequacy of protein is a healthy meat from healthy livestock. This will be obtained if the animals consume healthy feed. Feed is a single or mixed food ingredient, either processed or unprocessed, which is given to animals for survival, production, and reproduction. As one of the important and strategic factors, feed must be maintained in quality and safety. Healthy feeds should contain a complete nutritional value, are also not contaminated physically, chemically, and biologically (harmful micro-organisms).

Feed ingredients or feed composers generally can not stored for long. Indonesia's tropical climate with high temperature and high humidity will accelerate the decreasing of raw material quality and growth of fungus during storage. Several other factors that accelerate the 
damage of feed raw materials are postharvest handling, forgery and contamination on feed ingredients, as well as feed material production process. One of the microorganisms that often contaminates the feed is fungus or molds. Several types of molds that can be found in feed and ingredients are Aspergillus spp., Fusarium spp., Penicillium spp. and Mucor spp. (Atanda et al., 2011). Mold contamination can cause health problems such as mycosis for animals. Disruption or disease is not only caused by mold, but also by the toxin produced by the mold. Some factors that support the occurrence of contamination of molds and toxins in the feed mainly are moisture and temperature. In Indonesia, Aspergillus flavus is the dominant mold contaminant on feed and ingredients. Aspergillus produces mycotoxins called Aflatoxin (B1, B2, G1 and G2), which can contaminate food during production, harvesting, storage, and food processing, which the most toxic is aflatoxin B1 (Williams et al., 2004).

Meat bone meal (MBM) and poultry by product meal (PPM) are animal feed raw materials containing proteins and amino acids which are essential for animal growth. Affordable prices and good nutritional content make materials like them used as raw material for animal feed (Gumus and Baki, 2013; King'ori, 2012). Indonesia still unable to produce these animal feed raw materials so as to fulfill the need for raw materials, the government imports from several countries such as Australia, Canada, New Zealand and United States. Supervision of food safety through both materials is necessary and need to be tested with aflatoxin contamination on raw material of animal feed imported to Indonesia because the potential of causing healthy problems especially for animal and human.

This study aimed to measure the level of aflatoxin B1 produced by Aspergillus flavus on raw animal feedstock (MBM and PPM) imported through Tanjung Perak Port of Surabaya, and to provide scientific data and information for the Indonesian Agricultural Quarantine Agency in order to establish aflatoxin B1 testing policy. The hypothesis of this research is the occurrence of aflatoxin B1 produced by Aspergillus flavus in animal feed raw materials (MBM and PPM) imported through Tanjung Perak Port of Surabaya.

\section{Materials and methods}

Sampling was conducted at Tanjung Perak Port Surabaya. Sampling and testing were conducted from
September 2016 to January 2017. Samples taken are MBM and PPM imported from Australia, USA and New Zealand. Testing of aflatoxin B1 contamination was carried out using enzyme linked immunosorbent assay (ELISA) method. Samples that showed positive results with ELISA test were confirmed by high performance liquid chromatography (HPLC) testing method and also cultured on the Sabouraud Dextrose Agar (SDA) medium to isolate fungus produce aflatoxin, Aspergillus flavus.

\section{Sample size}

Samples tested were PPM originating from USA and MBM originating from USA, Australia and New Zealand. The sampling method follows The Grain Inspection Handbook (USDA, 2013). The sampling unit is selected on a container basis and uses a tool of shovels (long handles and short handles) and spears. Sample was taken $(300 \mathrm{~g})$, then inserted in a sterile plastic bag that had been code labeled, the date of collection and the country of origin of the sample.

The sample size is determined at $95 \%$ confidence level and calculated by equation of calculation formula of sample size according to Thrusfield (2006):

$$
n=\frac{4 P Q}{\left(\mathrm{~L}^{2}\right)}
$$

Where, $\mathrm{n}=$ Sample size; $\mathrm{P}=$ Prevalence assumption (30\%) (Bahri et al., 2005); $\mathrm{Q}=1-\mathrm{P} ; \mathrm{L}=$ Error desired $(10 \%)$.

Based on the calculation, the sample size was 84 samples from 3 countries. The number of samples was taken proportionally based on the frequency and average time of PPM and MBM input during January-June 2016 (Table 1).

Table 1. The sizes per country based on import frequency of PPM and MBM in January-June 2016.

\begin{tabular}{lllll}
\hline $\begin{array}{l}\text { Sl. } \\
\text { No. }\end{array}$ & Country & $\begin{array}{l}\text { Type of } \\
\text { feed raw } \\
\text { materials }\end{array}$ & $\begin{array}{l}\text { Frequency } \\
\text { Jan-Jun } \\
\mathbf{2 0 1 6}(\mathbf{x})\end{array}$ & $\begin{array}{l}\text { No. of } \\
\text { samples }\end{array}$ \\
\hline 1. & USA & PPM & 129 & 20 \\
2. & USA & MBM & 287 & 34 \\
3. & Australia & MBM & 89 & 12 \\
4. & New Zealand & MBM & 138 & 18 \\
& Total & & & $\mathbf{8 4}$ \\
\hline
\end{tabular}




\section{Sample MBM and PPM preparation}

Sample was filtered with a 20 mesh filter, then weighed as much as $\pm 5 \mathrm{~g}$ and then put into the Erlenmeyer tube. Methanol $70 \%$ prepared by diluting absolute methanol with aquadest (comparison 7: 3). Preparation extracts of sample solution $70 \%$ methanol solution was added as much as $25 \mathrm{ml}$ into an Erlenmeyer containing the sample. The samples were homogenized for 3 minutes (speed $200 \mathrm{rpm}$ ). The homogenized solution was filtered using Whatman paper no. 1. The filtrate solution is mixed with aquadest with a ratio of 1:1.

\section{ELISA aflatoxin test}

Microplate that has been coated with captured antibodies directed against anti-aflatoxin antibodies prepared. Standard solution and filtrate solution were added as much as $50 \mu \mathrm{l}$ per microplate well. A $50 \mu \mathrm{l}$ conjugate enzyme was added at each well, after which $50 \mu 1$ of anti-aflatoxin antibody solution was added to each well. The solution is mixed by rotating the plate slowly and incubated for 30 minutes at room temperature. The liquid in the well was removed by pressing the microplate on a clean filter paper to remove all liquids in the well. The washing solution was added as much as $250 \mu \mathrm{l}$ at each well, then all the liquid was removed and repeated the leaching twice. After washing, a substrate solution of $100 \mu \mathrm{l}$ was added to each well, mixing was done by rotating the plate slowly.

The plates were then incubated for 15 minutes at room temperature without light, then the stop solution was added as much as $100 \mu \mathrm{l}$ to each well and homogenized slowly. Readings on ELISA reader can be done 15 minutes after giving stop solution. Data were obtained based on sample or standard absorbance readings on ELISA reader with wavelength $450 \mathrm{~nm}$.

\section{Isolation and identification of Aspergillus sp.}

Isolation was performed based on Dharmaputra et al. (2013). Isolation was done from the $10^{-1}$ to $10^{-5}$ series dilution stage, then each dilution was continued by the pour plate method. PPM/MBM weighed $25 \mathrm{~g}$, then put into a $500 \mathrm{ml}$ measuring cup and added sterile distilled water to a volume of $250 \mathrm{ml}$, the result of the dilution was $1: 10^{-1}$ feed suspension. Then the suspension was transferred to a $500 \mathrm{ml}$ erlenmeyer tube and homogenized using a shaker at a rate of $150 \mathrm{rpm}$ for 1 minute. A total of $10 \mathrm{ml}$ was transferred to $250 \mathrm{ml}$ of an erlenmeyer tube and $90 \mathrm{ml}$ of sterile dehydrated water was added, then homogenized.

The result of the obtained suspension was $1: 100$ or $10^{-2}$. The dilution series was made up to a $10^{-5}$ dilution suspension. Subsequently each dilution was transferred into 2 Petri dishes with $1 \mathrm{ml}$ and added with $10 \mathrm{ml}$ of liquid DG18 medium. The suspension and liquid in the Petri dish were then homogenized to form 8 to be well mixed and subsequently incubated at room temperature for 5-7 days.

\section{Fungal macroscopic observations}

Each of the fungal colonies grown on Dichloran 18 Glycerol agar (DG18) medium were purified in Sabouraud Dextrose agar (SDA) medium, then incubated for 7 days and observed macroscopically. Observations including colony color, colony diameter, radial lines, and concentric circles. Fungal identification refers to the identification guidelines according to Larone (2002) and Campbell et al. (1996).

\section{Fungal microscopic observations}

Identification of fungi microscopically is done by using slide culture Riddel method, i.e., glass object and glass cover is inserted into Petri dish which then sterilized by using autoclave, then sterile SDA media on Petri dish is cut in cube shape and the piece is placed by using ose needle on top Glass object. The spores that have been grown are inoculated on the sides of the cube-shaped SDA media pieces by means of an ose needle, then covered with a glass cover and incubated at $35^{\circ} \mathrm{C}$ for 48 hrs. After incubation, the closing glass was transferred to a sterile object glass that had been dyeed with lactophenol cotton blue, then performed under microscope.

\section{HPLC test method}

\section{Sample extraction}

The method of extraction was adopted from the method developed by Wijayanti (2010). A total of 50 $\mathrm{g}$ of sample was weighed and mixed with $5 \mathrm{~g} \mathrm{NaCl}$. Methanol and aquadest in the 80:20 ratio were added to the mixture of $100 \mathrm{ml}$. Once homogenized, the mixture was filtered with filter paper. A total of $10 \mathrm{ml}$ of filtrate was mixed with $40 \mathrm{ml}$ of distilled water. 
The filtrate was filtered and accommodated in siring so that $10 \mathrm{ml}$ of volume was obtained. The immunoafinity purification system begins by passing $10 \mathrm{ml}$ of filtrate through the column at a rate of 1-2 drops/sec. Flushing was done with $10 \mathrm{ml}$ water at a rate of 2 drops/sec. Affinity columns were then eluted with $1 \mathrm{ml}$ methanol at the rate of 1-2 drops/sec. The resultant filtrate $(1 \mathrm{ml})$ was added to aquades test and injected into the HPLC system.

\section{Results analysis}

The results analysis was conducted qualitatively by looking at peak and quantitative profiles by measuring concentrations based on standard curves. Setting the HPLC system with a flow rate of $1 \mathrm{ml} / \mathrm{min}$, using methanol phase of motion : Aquadest (70:30), Shimpack ODS C18 diameter phase $5 \mu \mathrm{m}$ long $150 \mathrm{~mm}$. Wave reading on Y $365 \mathrm{~nm}$ ultraviolet spectrophotometer detector at room temperature $\left(25^{\circ} \mathrm{C}\right)$.

\section{Data analysis}

Data analysis used in this research is descriptive analysis by presenting data in the form of drawings and tables to describe the growing molds and aflatoxin B1 contamination.

\section{Results}

The test using competitive ELISA showed 47 of 84 samples (55.95\%) containing aflatoxin B1 contamination (Table 2). The highest results were PPM from USA as many as 15 of 20 samples (75\%), followed by MBM from USA 21 of 34 samples (61.76\%), MBM from New Zealand 9 of 18 samples (50.00\%) and MBM from Australia as many 2 of 12 samples (16.67\%) (Table 2).

Table 2. Results of aflatoxin B1 with competitive ELISA test.

\begin{tabular}{lllllll}
\hline & MBM & & & & PPM & \\
\cline { 2 - 7 } & USA & NZ & Australia & Amount & USA & Amount \\
\hline No. of Samples & 34 & 18 & 12 & 64 & 20 & 20 \\
Positive Samples & 21 & 9 & 2 & 32 & 15 & 15 \\
Positive (\%) & 61.76 & 50 & 16.67 & - & 75 & - \\
Average (ppb) & 1.69 & 2.61 & 4.70 & - & 3.97 & - \\
Min (ppb) & 1.01 & 1.18 & 3.85 & - & 1.04 & - \\
Max (ppb) & 4.95 & 7.45 & 5.56 & - & 11.9 & - \\
\hline
\end{tabular}

Samples tested by the HPLC (High Performance Liquid Chromatography) were taken from ELISA method results. The sample categorized into 3 groups: 1-4 ppb (3 samples), 5-8 ppb (3 samples), and 9-12 ppb (1 sample). There were 3 from 7 samples $(42.85 \%)$ showed positive results (Table 3 ). Those are
2 PPM samples from USA (0.18 ppb, and $0.06 \mathrm{ppb})$ and $1 \mathrm{MBM}$ sample from New Zealand (0.08 ppb). HPLC test also detects the presence of aflatoxin B2 (2.09 ppb and $0.02 \mathrm{ppb}$ ) in 2 PPM samples from USA and aflatoksin G1 (0.28 ppb) in sample PPM from USA (Table 3).

Tabel 3. Results of aflatoxin B1 with HPLC test.

\begin{tabular}{lllll}
\hline & MBM & & PPM & \\
\cline { 2 - 5 } & New Zealand & Amount & USA & Amount \\
\hline No. of samples & 2 & 2 & 5 & 5 \\
Positive samples & 1 & 1 & 2 & 2 \\
Positive (\%) & 50 & 50 & 40 & 40 \\
Average (ppb) & 0.08 & - & 0.10 & - \\
Min (ppb) & 0.08 & - & 0.03 & - \\
Max (ppb) & 0.08 & - & 0.18 & - \\
\hline
\end{tabular}

The fungal identification showed varied results. Which 6 from 12 samples contain Aspergillus niger, A. fumigatus and A. flavus, which most of them was Aspergillus fumigatus. This can be seen from the preparation either macroscopically or microscopically. Each of the cultured samples appeared some other fungus (Table 4). The cultural and microscopic characteristics of fungal species 
isolated from animal feed raw materials shown in Figs. 1-5.

Based on the culture of MBM and PPM conducted, it can be seen only 1 sample (sample number 7e, PPM from USA) which positively contains Aspergillus flavus. But there are several samples that also contain
Aspergillus spp. such as Aspergillus niger and Aspergillus fumigatus (sample number 36, MBM from New Zealand; sample number 12, MBM from Australia; sample no. 3, MBM from New Zealand; sample no. 33, PPM from USA; sample number 5, MBM from Australia; and sample number 9e, PPM from USA) (Table 5).

Tabel 4. Results of culture of PPM and MBM on SDA medium.

\begin{tabular}{|c|c|c|c|c|}
\hline No. & $\begin{array}{l}\text { No. of } \\
\text { samples }\end{array}$ & $\begin{array}{l}\text { Isolation } \\
\text { (Total colonies) }\end{array}$ & $\begin{array}{l}\text { No. of fungal } \\
\text { colonies }\end{array}$ & Identification \\
\hline 1. & 12 & 14 & 4 & Penicillium sp., A. fumigatus, Cladosporium sp. \\
\hline 2. & 36 & 11 & 4 & Cladosporium sp., A. fumigatus \\
\hline 3. & 54 & 3 & 3 & Madurella spp. \\
\hline 4. & 3 & 4 & 2 & Aspergillus fumigatus \\
\hline 5. & 9 & 4 & 3 & Cladosporium sp., Synchepalastrum sp., Fusarium sp. \\
\hline 6. & 33 & 7 & 3 & Cladosporium sp., Fusarium sp., Aspergillus sp. \\
\hline 7. & 5 & 9 & 6 & $\begin{array}{l}\text { Epidermophyton sp., Cunninghamella sp., Microsporum sp., } \\
\text { A. niger, Trichophyton sp. }\end{array}$ \\
\hline 8. & $2 \mathrm{e}$ & 28 & 1 & Cunninghamella sp. \\
\hline 9. & $6 e$ & 40 & 7 & $\begin{array}{l}\text { Fusarium, Cephalosporium sp., Trichophyton sp., Acremonium, } \\
\text { Chrysosporium sp. }\end{array}$ \\
\hline 10. & $2 \mathrm{a}$ & 13 & 5 & Scopulariopsis sp., Syncephalastrum sp., Chrysosporium sp. \\
\hline 11. & $7 \mathrm{e}$ & 21 & 6 & Rhizopus sp., Scopulariopsis sp., A. flavus \\
\hline 12. & $9 \mathrm{e}$ & 53 & 3 & Absidia sp., Emmonsia sp., A. niger \\
\hline
\end{tabular}

Tabel 5. Results of aflatoxin B1 contamination test with competitive ELISA method, HHPLC and culture.

\begin{tabular}{lllllll}
\hline No. & $\begin{array}{l}\text { No. of } \\
\text { samples }\end{array}$ & $\begin{array}{l}\text { Feed faw } \\
\text { materials }\end{array}$ & Country of origin & $\begin{array}{l}\text { Test } \\
\text { ELISA (ppb) }\end{array}$ & HPLC (ppb) & Kultur \\
\hline 1. & 12 & MBM & Australia & - & NT & - \\
2. & 36 & MBM & New Zealand & - & NT & - \\
3. & 54 & PPM & USA & - & NT & - \\
4. & 3 & MBM & New Zealand & $(3.51)$ & NT & - \\
5. & 9 & MBM & USA & $(1.79)$ & NT & - \\
6. & 33 & PPM & USA & $(1.23)$ & NT & - \\
7. & 5 & MBM & Australia & $(5.56)$ & NT & - \\
8. & $2 \mathrm{e}$ & MBM & USA & $(4.12)$ & NT & - \\
9. & $6 \mathrm{e}$ & PPM & USA & $(6.70)$ & - & - \\
10. & $2 \mathrm{a}$ & MBM & New Zealand & $(7.45)$ & - & - \\
11. & $7 \mathrm{e}$ & PPM & USA & $(11.9)$ & $(0.03)$ & + \\
12. & $9 \mathrm{e}$ & PPM & USA & $(8.13)$ & $(0.18)$ & - \\
13. & $5 \mathrm{e}$ & MBM & New Zealand & $(5.68)$ & $(0.08)$ & NT \\
14. & $10 \mathrm{e}$ & PPM & USA & $(2.21)$ & - & NT \\
15. & $11 \mathrm{e}$ & PPM & USA & $(4.40)$ & - & NT \\
\hline
\end{tabular}

*NT: not tested, (-): negative, (+): positive. 


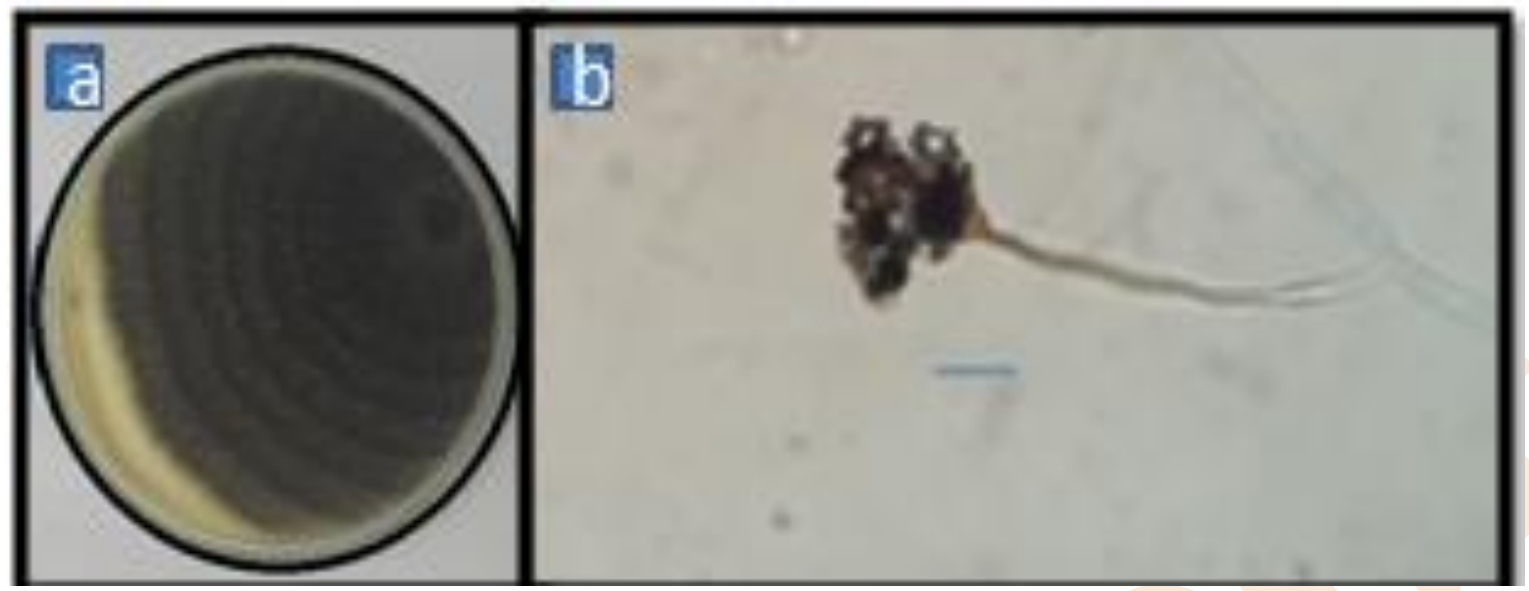

Fig. 1: Isolate 1. Aspergillus niger (a) Colony on SDA medium (b) Microscopic $20 \mu$.

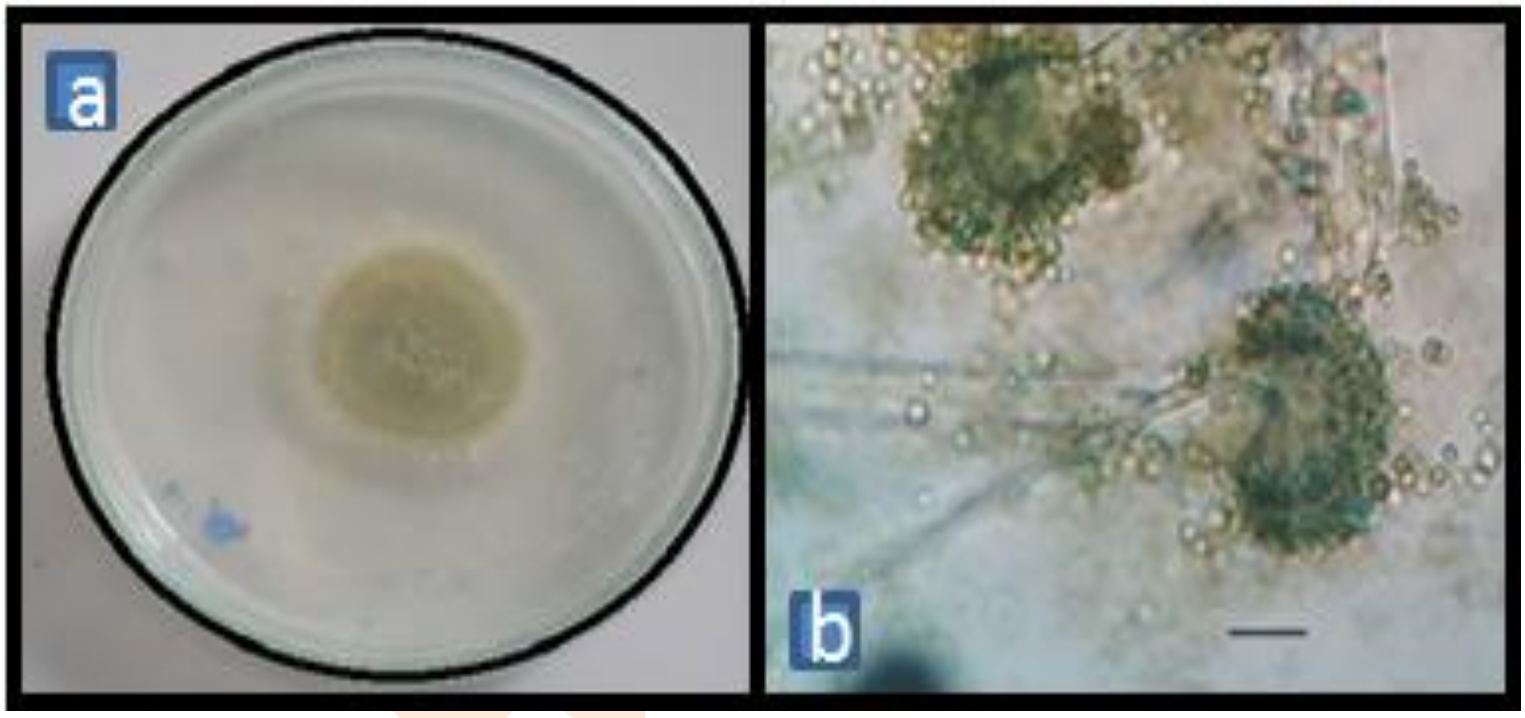

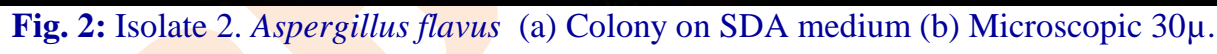

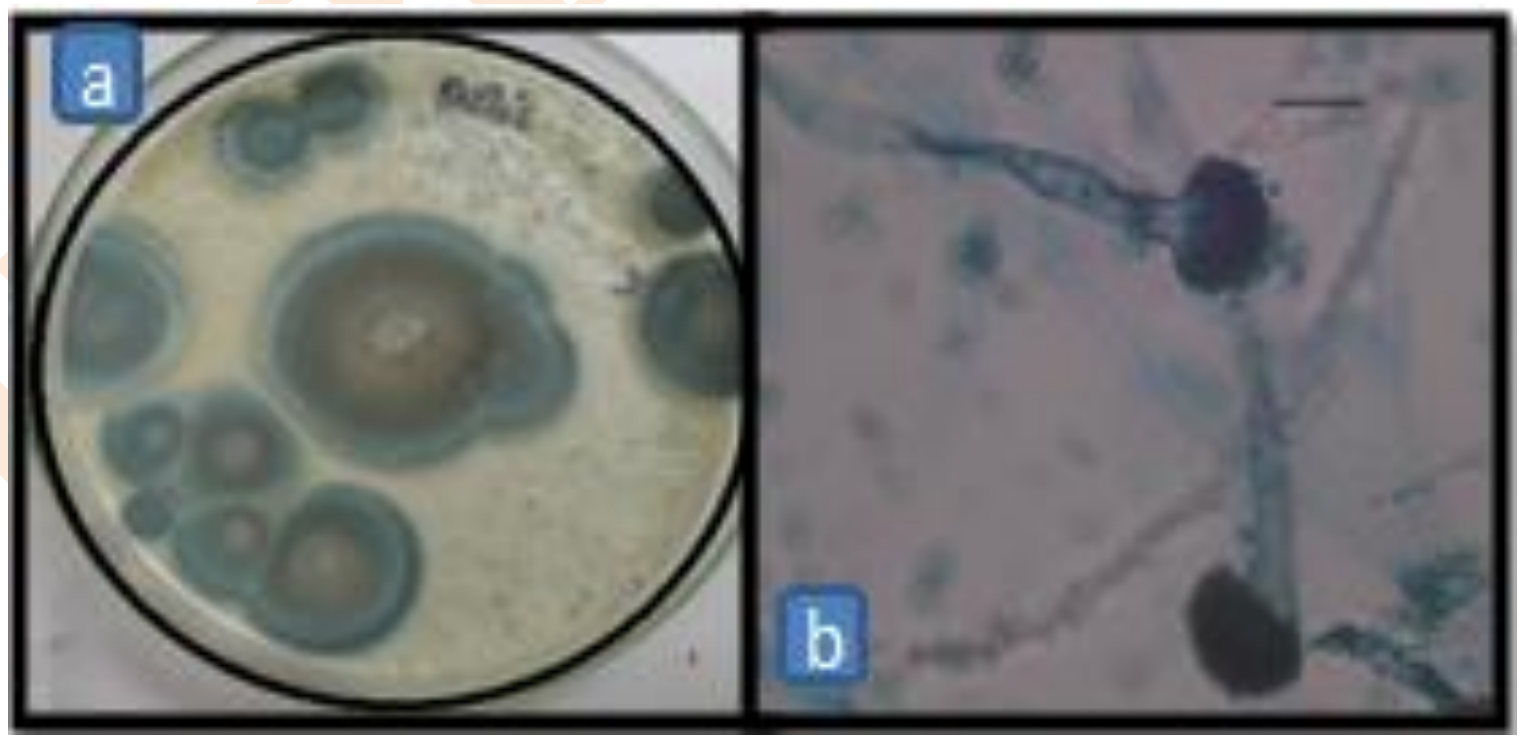

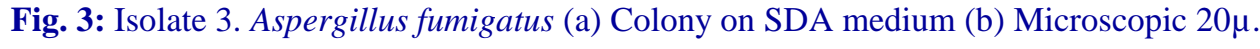




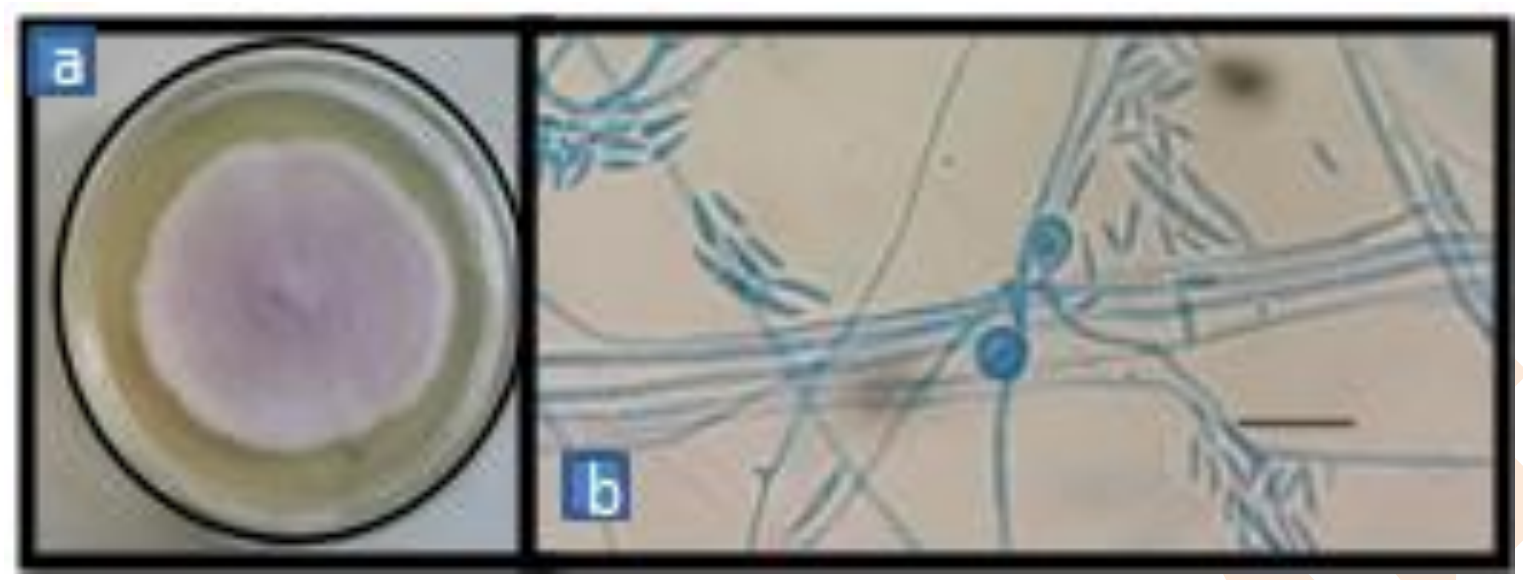

Fig. 4: Isolate 4. Fusarium sp. (a) Colony on SDA medium (b) Microscopic 20 $\mu$.

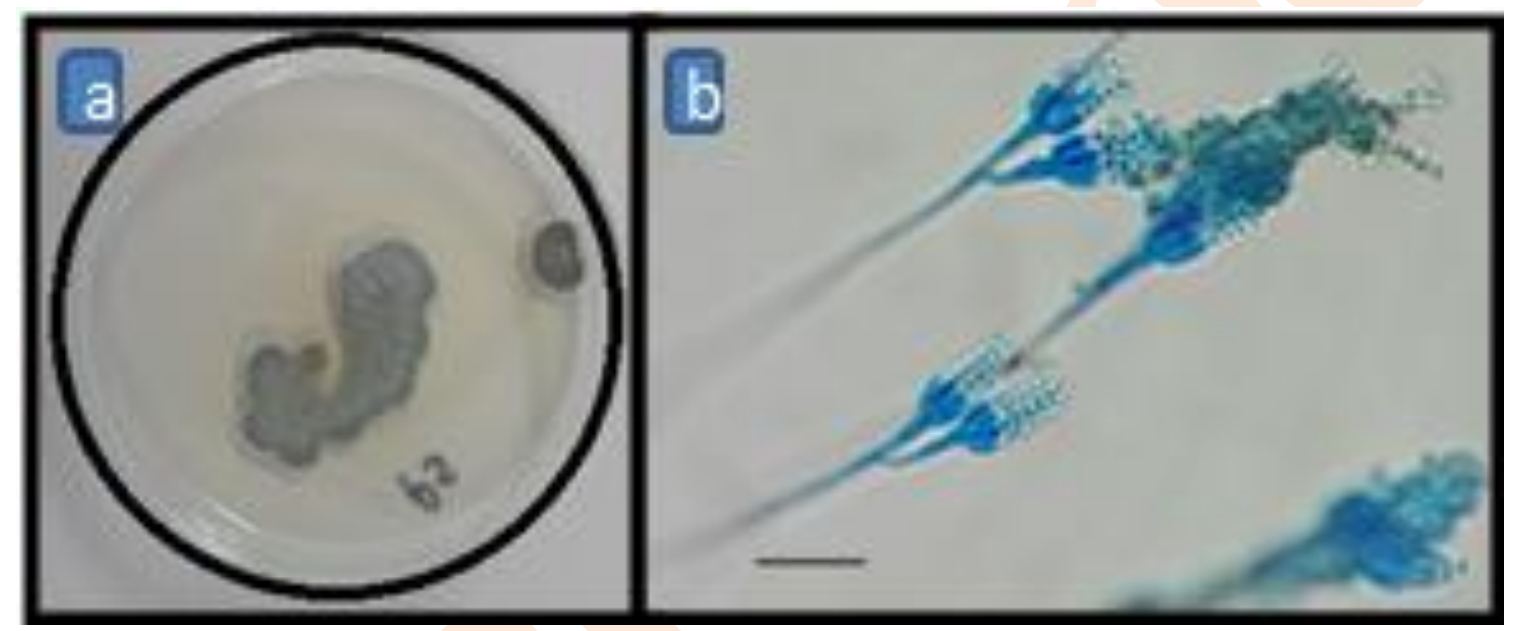

Fig. 5: Isolate 5. Penicillium sp. (a) Colony on SDA medium (b) Microscopic 20u.

\section{Discussion}

The incidence of aflatoxin B1 contamination is more than $50 \%$. Feed raw materials have a potential to be contaminated by Aflatoxin caused by two things. First is from the source of the animal itself, which previously consumed fodder that has been contaminated by Aflatoxin B1. Widiasuti (2006) says that aflatoxin B1 can be accumulated and deposited in animals body then part of its body is used as the basic material of animal raw feed. The absorption of aflatoxin in the upper part of the small intestine (80$90 \%$ of what is eaten is absorbed), then further processed in liver. In fact, aflatoxin are not toxic per se, but require metabolic conversion by hepatic enzymes to the metabolically active metabolite exoAFB 1-8, 9-epoxyde (AFBO) to exert its toxicity (Chen et al., 2013).

The metabolism of aflatoxin B1 is associated with efficient hepatic cytochrome P450-mediated bioactivation and deficient detoxification by glutathione S-transferases (GST) (Rawal et al., 2010). The second, aflatoxin contamintion can occur during the storage and transportation. Atanda (2011) reports that environmental conditions related to storage, climate or intrinsic factors such as fungal strain specificity, strain variation, and instability of toxigenic properties could influence the presence of mycotoxins in feeds. The increased aflatoxin contaamination is an accumulation of aflatoxin contaminants from harvest to storage. Storage conditions that produce environments with abundant oxygen contents spur mold to produce aflatoxin (Rahmianna et al., 2007).

MBM samples from USA showed a high incidence of aflatoxin B1. It may be derived from animal feed raw materials which already have been aflatoxicosis, or can also occur when feed ingredients is on the way to Indonesia. As we know, USA is the farest importer 
country and the ship board trips to Indonesia can be taken within weeks. The long journey or travel time and the long build up process in the home country can be a factor of Aspergillus spp. growth and produced aflatoxin. The quantity of aflatoxin is higher in commodities which comes from subtropical and tropical countries, where the environmental conditions are more suitable for mold growth and production of aflatoxin (Dani et al., 2012). Even the Aspergillus spp. has already gone by the treatment, the aflatoxin will still exist on the product.

The PPM sample from USA results seen as much as 15 of $20(75 \%)$ positive samples contained aflatoxin B1. Based on the composition or content of the PPM itself, which comprises parts of the poultry such as the neck, legs, eggs, intestines and so forth, which is where aflatoxin deposits, it is probably that aflatoxin has been established in the country of origin USA. PPM also contains higher methionine and tryptophan than MBM, both of them are amino acids that can push aflatoxin produced by $A$. flavus and A. parasiticus (Payne and Hagler 1983). The results of research conducted by Galuh (2016), reports that aflatoksin B1 has been found on raw materials of animal feed imported through port of Tanjung Priuk, Jakarta. The aflatoxin B1 contamination comes from Australia (MBM), Canada (MBM), and United States (PPM).

The concentration of aflatoxin B1 contaminants in samples examined by competitive ELISA method value ranged from 1.01 to $11.9 \mathrm{ppb}$. According to SNI 7652.3: 2011, the value of the result does not exceed the maximum limit of aflatoxin contamination (40 ppb). It means aflatoxin contaminant levels still be tolerated to enter Indonesia.

There are also other fungi that grow in the culture medium, but most are the fungus that contaminate the MBM and PPM during transport, hoarding, or in the laboratory. Khotimah et al. (2015) found some potential contaminant fungus such as Aspergillus flavus, A. fumigatus, A.niger, Penicillium citrinum, Cladosporium cladosporioides, and Fusarium verticillioides in layer feed.

AFB1 contamination in animal feed raw is probably occur in the country of origin or at the time of transportation and stockpiling in the destination country. Although processing has been done in the country of origin, distant travel and container conditions may be a predisposition factor for the occurrence of aflatoxin fungus. The degree of humidity and temperature is crucial for Aspergillus spp. All containers used to transport animal feed raw materials are not equipped with temperature control and humidity devices. Temperature during transport and build up ranges from $28-35^{\circ} \mathrm{C}$ and $80-92 \%$ moisture, which is suitable for Aspergillus spp. growing and producing toxin. Aspergillus spp. grows and produces toxin at optimum temperature $25-32^{\circ} \mathrm{C}$, $85 \%$ humidity, and water content $18 \%$ (Mousa et al., 2013).

The fungal identification showed Aspergillus flavus in 1 sample only (PPM sample from USA). It was the sample with highest ELISA (11.9 ppb) and positive value on HPLC test. Of the 7 positive samples of competitive ELISA tested, only 3 samples showed positive HPLC. This is probably due to the influence of protein content, pigment, and amino acids that estimated could increase toxin levels in testing by competitive ELISA methods (Rossi et al., 2012). Comparison of the ELISA method, ability to detect aflatoxins to be rugged, sensitive, accurate, precise and effective comparable to HPLC for measuring total aflatoxins ranging from 4 to $40 \mathrm{ppb}$ (Zheng et al., 2005).

According to all samples, PPM is the most widely tested with competitive ELISA method which shows the highest incidence of Aflatoxin B1 (75\%), while MBM from all samples tested $50 \%$ positive for Aflatoxin B1. Both types of animal feed raw materials (PPM and MBM) comes from the United States. Rodrigues et al. (2007) reports that the incidence rate of Aflatoxin contamination in animal feed in the USA tested by ELISA method was $20 \%$.

Aflatoxin in animal feed raw amounts $<40 \mathrm{ppb}$ actually does not cause major problems, because the body will try to remove through the mechanisms of bioactivation, conjugation and deconjugation. This metabolism occurs in liver, but some are metabolized in blood and other organs. In these three stages, the body attempts to reduce the toxic effects of aflatoxin. Symptoms that may arise usually include decreased appetite, delayed growth and mild irritation due to tissue death (necrosis). Aflatoxin will be released by the body through bile, milk, egg, and urine. When aflatoxin can not be excreted from the body, there will be pathological changes and cause some symptoms 
such as birth defects (teratogenic effects), cancer (human and animals) and the death (Wu et al., 2014).

\section{Conclusion}

Competitive ELISA and HPLC methods have been used to determine aflatoxin B1 contamination in feed raw materials (MBM and PPM) imported through Tanjung Perak Port Surabaya and its association with Aspergillus flavus. There are 47 samples (15 PPM samples and 32 MBM samples) containing Aflatoxin B1. Of the 47 samples, there were Aspergillus flavus, the main fungi producer of aflatoxin B1. There are also Aspergillus niger, Aspergillus fumigatus and Fusarium sp. which can also produce aflatoxin.

\section{Conflict of interest statement}

Authors declare that they have no conflict of interest.

\section{References}

Atanda, S.A., Pessu, P.O., Agoda, S., Isong, I.U., Adekalu, O.A., Echendu, M.A., Falade, T.C., 2011. Fungi and mycotoksins in stored foods. Afr. J. Microbiol. Res. 5(25), 4373-4382.

Bahri, S., Maryam, R., Widiastuti, R., 2005. Cemaran aflatoksin pada bahan pakan dan pakan di beberapa daerah propinsi Lampung dan Jawa Timur. JITV. 10(3), 236-241.

Campbell, C.K., Johnson, E.M., Philpot, C.M., Warnock, D.W., 1996. Identification of Pathogenic Fungi. Public Health Laboratory Service, London (UK).

Chen, X., Grenier, B., Applegate, T.J., 2013. Aflatoxins in Poultry, Purdue University, Indiana (US).

Dani, I.W., Nurtjahja, K., Zuhra, C.F., 2012. Penghambatan pertumbuhan Aspergillus flavus dan Fusarium moniliforme oleh ekstrak salam (Euginea polyantha) dan kunyit (Curcuma domestica). Saintia Biologi. 1(1), 8-14.

Dharmaputra, O.S., Ambarwati, S., Retnowati, I., Windayarani, A., 2013. Physical quality, Aspergillus flavus population and aflatoxin B1 content of raw peanut kernels. J. Fitopatol. Indones. 9(4), 99-106.

Galuh, A.H., 2016. Aflatoksin B1 Contamination Prevalence in Animal Feed Raw Material Imported Through Tanjung Priok Seaport [thesis]. Bogor Agricultural University, Bogor (ID).

Gumus, E., Baki, A., 2013. Effect of poultry by product meal on growth performance and fatty acid composition of carp (Cyprinus carpio) fry. Turk. J.
Fish. Aquat. Sc.13, 827-834.

Khotimah, K., Indrawati, A., Latif, H., 2015. Identification of fungi and mycotoxin in layer feed sold in traditional markts of Bogor, Indonesia. Int. J. Curr. Biosci. Plant Biol. 2(8), 97-104.

King'ori, A.M., 2012. Management of poultry by product-utilization of feather. Int. J. Livest. Res. $2(3), 58-64$.

Larone, D.H., 2002. Medically Important Fungi: A Guide to Identification (4th Edn.). ASM Press, Washington DC (US).

Mousa, W., Ghazali, F.M., Jinap, S., Ghazali, H.M., Radu, S., 2013. Modeling growth rate and assessing aflatoxins production by Aspergillus flavus as a function of water activity and temperature on polished and brown rice. J. Food Sci. 78(1), 56-63.

Rahmianna, A.A., Taufiq, A., Yusnawan, E., 2007. Effect of harvest timing and postharvest storage conditions on aflatoxin contamination in groundnuts harvested from the Wonogiri regency in Indonesia. J. SAT Agric. Res. 5(1), 1-3.

Rawal, S., Kim, J.E., Coulombe, Jr. R., 2010. Aflatoxin B1 in poultry: Toxicology, metabolism and prevention. Res. Vet. Sci. 89, 325-331.

Rodrigues, P., Soares, C., Kozakiewicz, Z., Paterson, R.R.M., Lima, N., Venâncio, A., 2007. Identification and characterization of Aspergillus flavus and aflatoxins. In: Communicating Current Research and Educational Topics and Trends (Ed.: Méndez, V.A.). Instituto Politecnico de Braganta (PT): Biblioteca Digital.

Rossi, C.N., Takabayashi, C.R., Ono, M.A., Saito, G.H., Itano, E.N., Kawamura, O., Hirooka, E.Y., Ono, E.Y.S., 2012. Immunoassay based on monoclonal antibody for aflatoxin detection in poultry feed. J. Food Chem. 132, 2211-2216.

Thrusfield, M., 2006. Veterinary Epidemiology (3rd Edn.). Blackwell Science, Oxford (GB).

United States Department of Agricultural (USDA), 2013. Grain Inspection Handbook. Book I: Sampling. United States Department of Agricultural, Washington DC (US).

Widiastuti, R., 2006. Mycotoxin: Its effect on animal health and its residues in animal products and its control. Wartazoa. 16, 116-127.

Wijayanti, A.D., 2010. Penentuan kadar aflatoksin B1 dalam pakan broiler secara kromatografi cair kinerja tinggi dengan pemurnian secara imunoafinitas. J Sain Vet. 28(2), 98-103.

Williams, J.H., Phillips, T.D., Jolly, P.E., Stiles, J.K., Jolly, C.M., Aggarwal, D., 2004. Human 
aflatoksikosis in developing countries: A review of toxicology, exposure, potential helath consequences, and interventions. Am. J. Clin. Nutr. 80(5), 110611022.

Wu, F., Groopman, J.D., Pestka, J.J., 2014. Public health impacts of foodborne mycotoxins. Annu. Rev. Food
Sci. Technol. 5, 351-372.

Zheng, Z., Humphrey, C. W., King, R. S., Richard, J. L., 2005. Validation of an ELISA test kit for the detection of total aflatoxins in grain and grain products by comparison with HPLC. Mycopathol. $159,255-263$.

\section{How to cite this article:}

Arios, Y. P., Indrawati, A., Pamungkas, J., 2017. Aflatoxin B1 contamination correlation with Aspergillus flavus in animal feed raw materials imported through the Port of Tanjung Perak Surabaya, Indonesia. Int. J. Curr. Res. Biosci. Plant Biol. 4(7), 23-32. doi: https://doi.org/10.20546/ijcrbp.2017.407.003 